\title{
PENGARUH KANDUNGAN ABU DAN ZAT TERBANG TERHADAP MAKSIMUM FLUIDITAS BATUBARA FORMASI TANJUNG DI DAERAH SEKAKO, PROVINSI KALIMANTAN TENGAH
}

\author{
THE INFLUENCE OF ASH AND VOLATILE MATTER CONTENTS ON \\ MAXIMUM FLUIDITY OF TANJUNG FORMATION COAL IN SEKAKO AREA, \\ CENTRAL KALIMANTAN PROVINCE
}

\author{
Beny Wiranata, Hendra Amijaya*, Ferian Anggara, \\ dan Deddy Nan Setya Putra Tanggara \\ Departemen Teknik Geologi, Fakultas Teknik, Universitas Gadjah Mada \\ *hamijaya@gadjahmada.edu
}

\begin{abstract}
ABSTRAK
Batubara bituminus volatil rendah sampai tinggi pada Formasi Tanjung di Provinsi Kalimantan Tengah dikenal berpotensi sebagai batubara metalurgi atau batubara kokas. Maksimum fluiditas batubara merupakan salah satu parameter penting yang berhubungan erat dengan kualitas kokas yang dihasilkan. Penelitian ini bertujuan untuk mengetahui hubungan antara kandungan abu dan zat terbang terhadap maksimum fluiditas batubara pada Formasi Tanjung di daerah Sekako dan sekitarnya, Provinsi Kalimantan Tengah. Empat conto batubara lapisan A dan enam conto batubara lapisan B dari Formasi Tanjung, diambil dengan menggunakan metoda pemercontohan saluran. Conto batubara yang diambil didominasi oleh litotipe batubara mengilap dan batubara mengilap berlapis. Conto tersebut kemudian dibawa ke laboratorium untuk dianalisis proksimat serta analisis Gieseler plastometer. Hasil analisis kimia menunjukkan conto batubara memiliki kandungan abu berkisar dari 2,79 sampai 9,05 wt\%, adb, kandungan zat terbang 35,14 sampai 39,50 wt\%, adb dan maksimum fluiditas 22.263 sampai $49.029 \mathrm{ddpm}$. Hasil evaluasi menunjukkan bahwa di daerah penelitian, mempunyai kandungan abu berkorelasi negatif kuat $(r=-0,656$; $R^{2}=0,431$ ) dan tidak berpengaruh signifikan (sig. 0,055 >0,05) terhadap maksimum fluiditas batubara. Sementara kandungan zat terbang berkorelasi positif sangat kuat $\left(r=0,794 ; R^{2}=\right.$ 0,6301) dan berpengaruh signifikan (sig. 0,003<0,05) terhadap maksimum fluiditas batubara. Semakin tinggi kandungan abu, maka maksimum fluiditas batubara semakin rendah dan sebaliknya semakin tinggi kandungan zat terbang, maka maksimum fluiditas batubara semakin tinggi. Hubungan kandungan zat terbang dengan maksimum fluiditas batubara dapat dinyatakan dengan persamaan $y=6327,9 x-200248$.
\end{abstract}

Kata kunci: Batubara, abu, zat terbang, maksimum fluiditas, Formasi Tanjung

\section{ABSTRACT}

High to low volatile bituminous coals of Tanjung Formation in Central Kalimantan Province is known to be potentially used as a metallurgical or coking coal. Coal maximum fluidity is one important parameter which is strongly connected to the quality of the coke produced. This study aims to determine the relationship between coal maximum fluidity and its volatile matter and ash content. Four coal from $A$ seam and 6 coal from $B$ seam of Tanjung Formation in Sekako area were sampled using a ply by ply channel sampling method. Samples are dominated by bright coal and banded bright coals lithotype. All coal samples are subjected to proximate and Gieseler plastometer analysis in the laboratory. The coal samples Laboratory results show that coal in the study area have ash content ranging from 2,79 to 9,05 (wt\%, adb), volatile matter contents varies from 35,14 to 39,50 (wt\%, adb) and coals maximum fluidity varies from 22263 to 49029 (ddpm). Further data evaluation indicates that in the study area, coal ash content are negatively correlated $(r=-0.656, R 2=0.431)$ and 
had no significant effect on the maximum of coal fluidity ( $r=-0,656, R 2=-0,431$ and sig. $0,055>0,05)$. On the other hand, coal volatile matter are positively correlated $(r=0.794 ; R 2$ $=0.6301)$ and had a significant effect (sig. $0.003<0.05)$ on the maximum fluidity of coal. The increase of ash content causes the decrease of coal maximum fluidity, whereas the increase of coal volatile matter causes the increase of coal maximum fluidity. The correlation of volatile matter content and coal maximum fluidity can be expressed by an equation of $y=6327,9 x-200248$.

Keywords: coal, ash, volatile matter, coal maximum fluidity, Tanjung Formation

\section{PENDAHULUAN}

Batubara pada umumnya digunakan sebagai sumber energi pembangkit listrik ataupun sebagai bahan baku pembentuk kokas dalam industri metalurgi. Sebagai sumber energi, konversi batubara menjadi energi yang lebih ramah lingkungan juga telah banyak dikembangkan, diantaranya melalui proses liquifaksi (hidrogenasi) dan gasifikasi (Thomas, 2013; Miller, 2005; Suarez-Ruiz dan Crelling, 2008; Speight, 2013). Dalam industri metalurgi, batubara dapat digunakan baik sebagai sumber energi pembakaran atau pemanasan (fuel), maupun sebagai bahan baku utama pembentuk kokas yang berfungsi sebagai agen pereduksi oksida bijih dan sebagai material permeabel di dalam teknologi blast furnace untuk menghasilkan besi dan baja (Miller, 2005; Diaz-Faes et al. 2007; Huda, 2013).

Cekungan Kutai dan Cekungan Barito yang terletak di Pulau Kalimantan merupakan cekungan utama penghasil batubara (Friederich et al. 2016; Friederich dan van Leeuween, 2017). Beberapa batubara peringkat tinggi di Indonesia yang dinyatakan sebagai batubara metalurgi umumnya terletak di daerah Kalimantan Timur dan Kalimantan Tengah (Daulay et al. 2015). Batubara Eosen yang terletak pada upper portion Sungai Mahakam di Kalimantan Timur juga diidentifikasi memiliki sifat sebagai batubara metalurgi (Madiadipoera dan Tramifov, 1969). Batubara yang memiliki potensi sebagai batubara metalurgi biasanya terdapat pada bagian tengah dan bagian bawah dari Formasi Tanjung di Cekungan Barito dan Formasi Batu Ayau di Cekungan Kutai atas (Nas dan Hidartan, 2010).

Dalam mengkarakterisasi batubara metalurgi, sifat fluiditas (disebut juga sebagai sifat caking) perlu diketahui untuk mengevaluasi kemampuan batubara dalam menggumpal (agglomerating) saat proses karbonisasi. Dalam proses karbonasi, batubara akan terlebih dahulu membentuk fase cair (dalam proses pembuatan kokas dikenal sebagai plastic stage) sebelum akhirnya membentuk residu padatan yang bersifat porous yang disebut kokas (Miller, 2005; Thomas, 2013; Speight, 2013). Maksimum fluiditas merupakan salah satu parameter penting yang sangat berkaitan dengan kualitas dan kekuatan kokas yang dihasilkan (Diez et al. 2002; Diaz-Faes et al. 2007; Tsubouchi et al., 2014; Smedowski dan Piechaczek, 2016; Vega et al. 2017). Maksimum fluiditas juga merupakan salah satu parameter yang digunakan dalam proses pencampuran (blending) batubara untuk menghasilkan produk kokas yang berkualitas (Thomas, 2013; Mochizuki et al. 2017).

Beberapa parameter atau faktor yang mempengaruhi maksimum fluiditas batubara yaitu komposisi maseral dan peringkat batubara (rank), ukuran butir (grain size), kimia batubara (chemistry), kimia abu batubara (chemistry of ash), penurunan kualitas batubara akibat penyimpanan yang lama (aging) dan oksidasi (Ryan et al. 1998; Diaz-Faes et al. 2007; Suarez-Ruiz dan Crelling, 2008).

Terkait dengan peringkat batubara, salah satu parameter yang bisa menjadi acuan 
adalah kandungan zat terbang. Dalam batubara, zat terbang secara komposisi kimia didominasi oleh fraksi non aromatic (Taylor et al. 1998). Kandungan fraksi non aromatik yang tinggi akan menyebabkan tingginya kandungan elemen hidrogen $(\mathrm{H})$ dan peningkatan rasio hidrogen/karbon (rasio $\mathrm{H} / \mathrm{C}$ ) dalam batubara. Rasio $\mathrm{H} / \mathrm{C}$ yang tinggi akan menghasilkan tar dan gas yang tinggi pada saat proses karbonisasi, sehingga kokas yang dihasilkan sedikit (Miller, 2005; Suarez dan Crelling, 2008). Seiring dengan meningkatnya peringkat dari batubara maka kandungan zat terbang di dalam batubara akan semakin menurun.

Abu juga merupakan parameter yang penting dalam karakterisasi batubara. Abu adalah residu sisa hasil pembakaran batubara (Thomas, 2013; Miller, 2005; Sukandarrumidi, 2009; Riddell and Han, 2017). Abu tersebut berasal dari komponen non organik yang memiliki sifat sebagai material yang tidak bisa terbakar di dalam batubara (Sukandarrumidi, 2009). Abu di dalam batubara berpengaruh signifikan terhadap maksimum fluiditas batubara (Arslan dan Kemal, 2006). Kandungan abu yang tinggi akan berdampak negatif terhadap kekuatan dan kemampuan kokas di dalam blast furnace (Ryemshak dan Jauro, 2016; Riddell dan Han, 2017).

Batubara di daerah Sekako dan sekitarnya telah diteliti diantaranya oleh Isnadiyati, dkk. (2018). Hanya saja, penelitian tersebut tidak membahas potensi batubara Sekako sebagai batubara metalurgi. Penelitian yang dilakukan oleh penulis bertujuan untuk mengetahui potensi metalurgi dari batubara Sekako, dengan fokus pada hubungan antara kandungan zat terbang dan abu serta pengaruhnya terhadap maksimum fluiditas batubara Formasi Tanjung di daerah tersebut.

\section{GEOLOGI}

Daerah penelitian berada di daerah Sekako, Provinsi Kalimantan Tengah
(Gambar 1). Secara geologi berada pada bagian utara dari Cekungan Barito (Gambar 2). Cekungan Barito merupakan salah satu cekungan yang terbentuk pada Kenozoik Awal di Asia Tenggara (Doust and Sumner, 2007; Hall and Morley, 2004; Hamilton, 1979; Witts et al. 2012).

Pada umumnya struktur yang berkembang pada Cekungan Barito dapat terbagi menjadi dua rezim tektonik (Darman dan Sidi, 2000). Rezim pertama berupa rezim transtensional yang menghasilkan sesar geser sinistral yang memiliki arah orientasi barat laut - tenggara dan rezim yang kedua berupa rezim transpresional yang diikuti proses convergent uplift, reaktivasi dan pembalikan struktur yang telah ada sebelumnya dan menghasilkan wrenching, lipatan serta patahan.

Secara stratigrafi regional Cekungan Barito dapat dibagi menjadi 4 megasequences yaitu prerift sequence, synrift sequence, postrift sequence dan syninversion sequence (Satyana dan Silitonga, 1994). Formasi Tanjung merupakan bagian dari synrift sequence dan postrift sequence (Satyana dan Silitonga, 1994).

Cekungan Barito merupakan salah satu cekungan Tersier di Indonesia yang mempunyai potensi sumber daya energi cukup besar, salah satunya berupa batubara (Heryanto, 2010). Formasi pembawa batubara di Cekungan Barito yang berada di Kalimantan Tengah umumnya adalah Formasi Tanjung, Formasi Batu Ayau, Formasi Batupasir Haloq, Formasi Montalat dan Formasi Warukin (Soetrisno et al. 1994; Supriatna et al. 1995). Batubara bituminus yang potensial sebagai batubara metalurgi biasanya ditemukan pada Formasi Tanjung dan Formasi Batu Ayau (Nas dan Hidartan, 2010). Batubara bituminus Formasi Tanjung di Daerah Lemo memiliki kandungan abu dan sulfur yang rendah serta nilai kalori yang tinggi sehingga berpotensi sebagai batubara metalurgi (Amarullah, 2009). 


\section{MAKALAH ILMIAH}

Daerah penelitian secara geologi berada pada Formasi Tanjung (Gambar 3). Formasi Tanjung berumur Eosen Akhir hingga Oligosen dan bagian bawah formasi tersebut tersusun atas batupasir, serpih, batulanau dan konglomerat polimik. Formasi Tanjung bagian atas tersusun atas batupasir kuarsa, batulanau, batugamping dan batubara (Soetrisno et al., 1994).

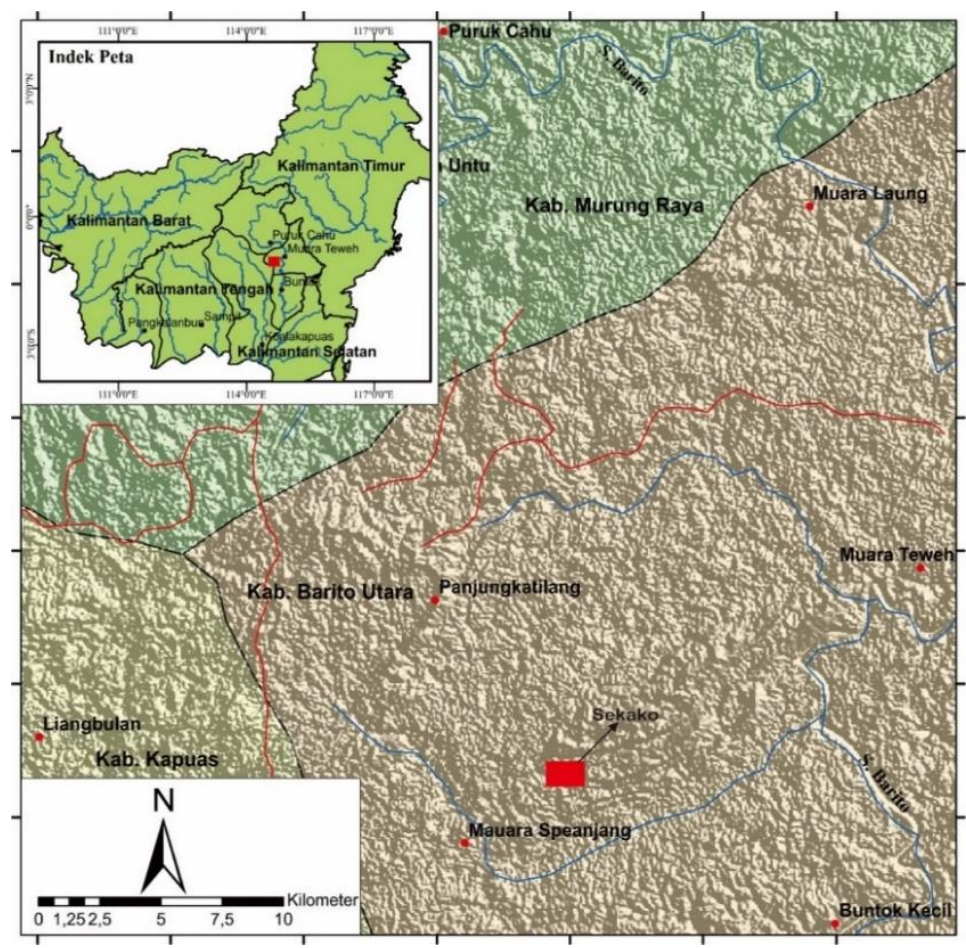

Gambar 1. Peta lokasi daerah penelitian ditunjukan dengan kotak berwarna merah (modifikasi peta dari geospatial.bnpb.go.id)

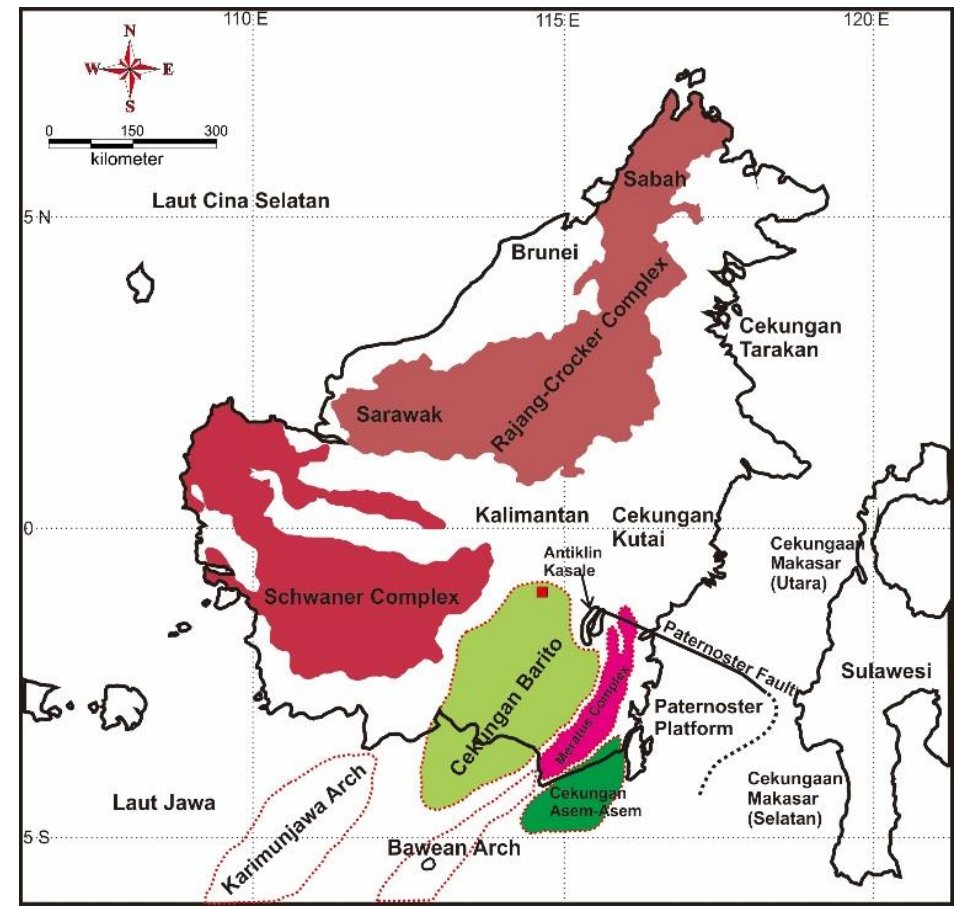

Gambar 2. Fisiografi Pulau Kalimantan, daerah penelitian kotak berwarna merah (modifikasi dari Witts et al. 2009) 


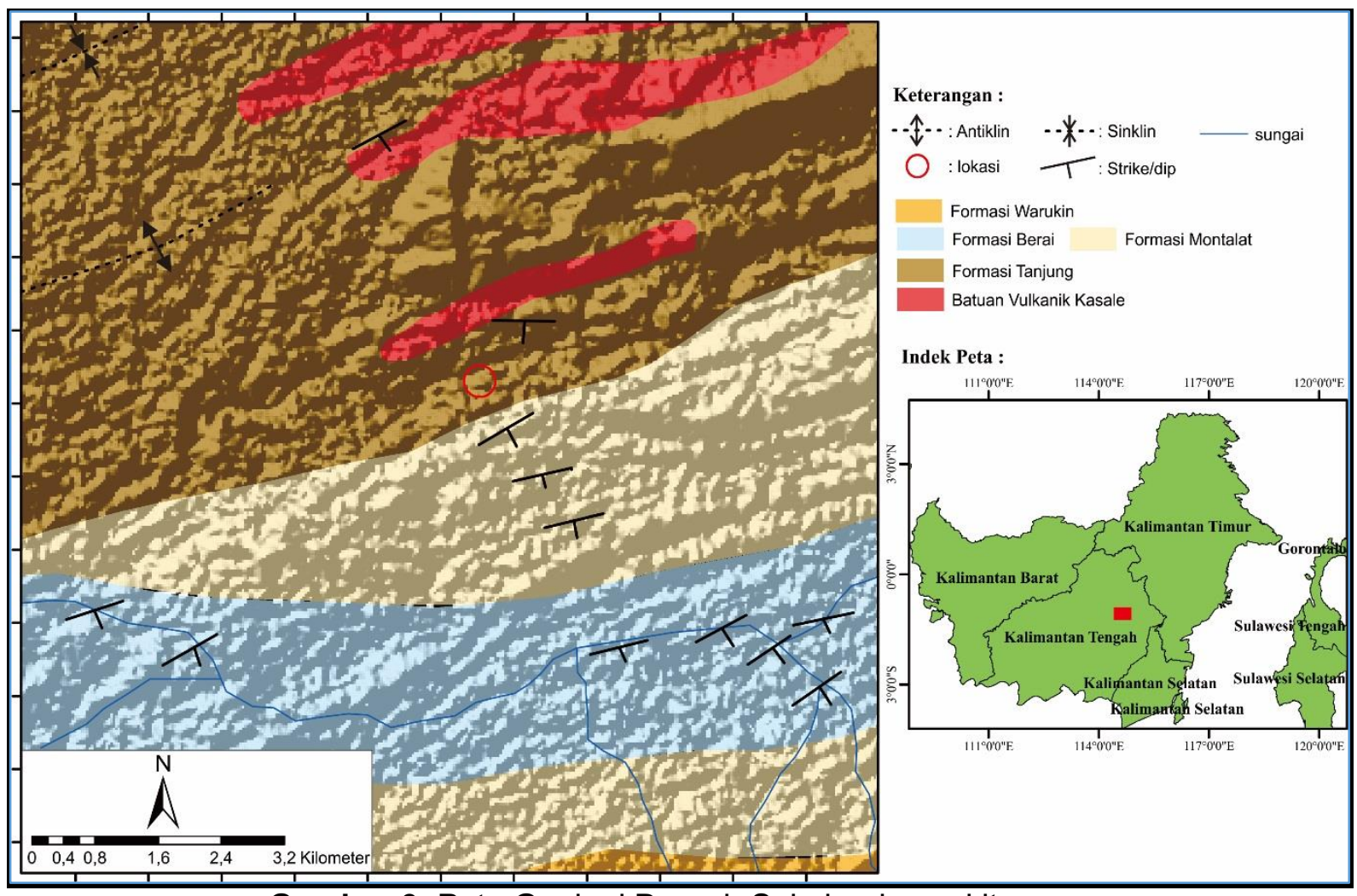

Gambar 3. Peta Geologi Daerah Sekako dan sekitarnya,

diambil dari Peta geologi Regional Lembar Buntok (Soetrisno dkk., 1994).

Lokasi pengambilan conto ditandai dengan lingkaran

\section{METODOLOGI}

Pengambilan conto pada singkapan batubara permukaan di Daerah Sekako, Kalimantan Tengah (Gambar 4) dilakukan dengan menggunakan metode pemercontohan saluran dari masing masing ply. Sebanyak 10 conto batubara diambil dari dua lapisan batubara yang diindikasi sebagai batubara metalurgi pada Formasi Tanjung di daerah penelitian, yaitu empat conto dari lapisan $A$ dan enam conto dari lapisan B (Gambar 4).

Analisis suksesi vertikal dan deskripsi litotipe batubara didasarkan atas warna, kilap, dan rekahan serta mengacu pada standar Australian (Tabel 1) yang sudah dimodifikasi (Lamberson et al. 1991). Analisis laboratorium terhadap conto batubara dilakukan di Laboratorium PT Sucofindo di Surabaya dan PT Talent Orbit Prima (PT TOP) di Desa Buhut, Kabupaten Kapuas, Kalimantan Tengah yang meliputi analisis kandungan zat terbang yang mengacu pada ASTM D 3175 , analisis kandungan abu mengacu pada ASTM D 3174, dan analisis Gieseler plastometer mengacu pada ASTM D 2639.

Analisis kandungan abu dan zat terbang serta pengaruhnya terhadap maksimum fluiditas batubara dilakukan dengan pendekatan statistik regresi linier sederhana. Hasil dari analisis tersebut disajikan dalam bentuk tabel dan grafik diagram pencar. Analisis dilakukan dengan tingkat kepercayaan 95\% ( $\alpha=$ 0,05 ). Analisis tersebut dilakukan dengan bantuan perangkat lunak Ms. Excel. 


\section{MAKALAH ILMIAH}

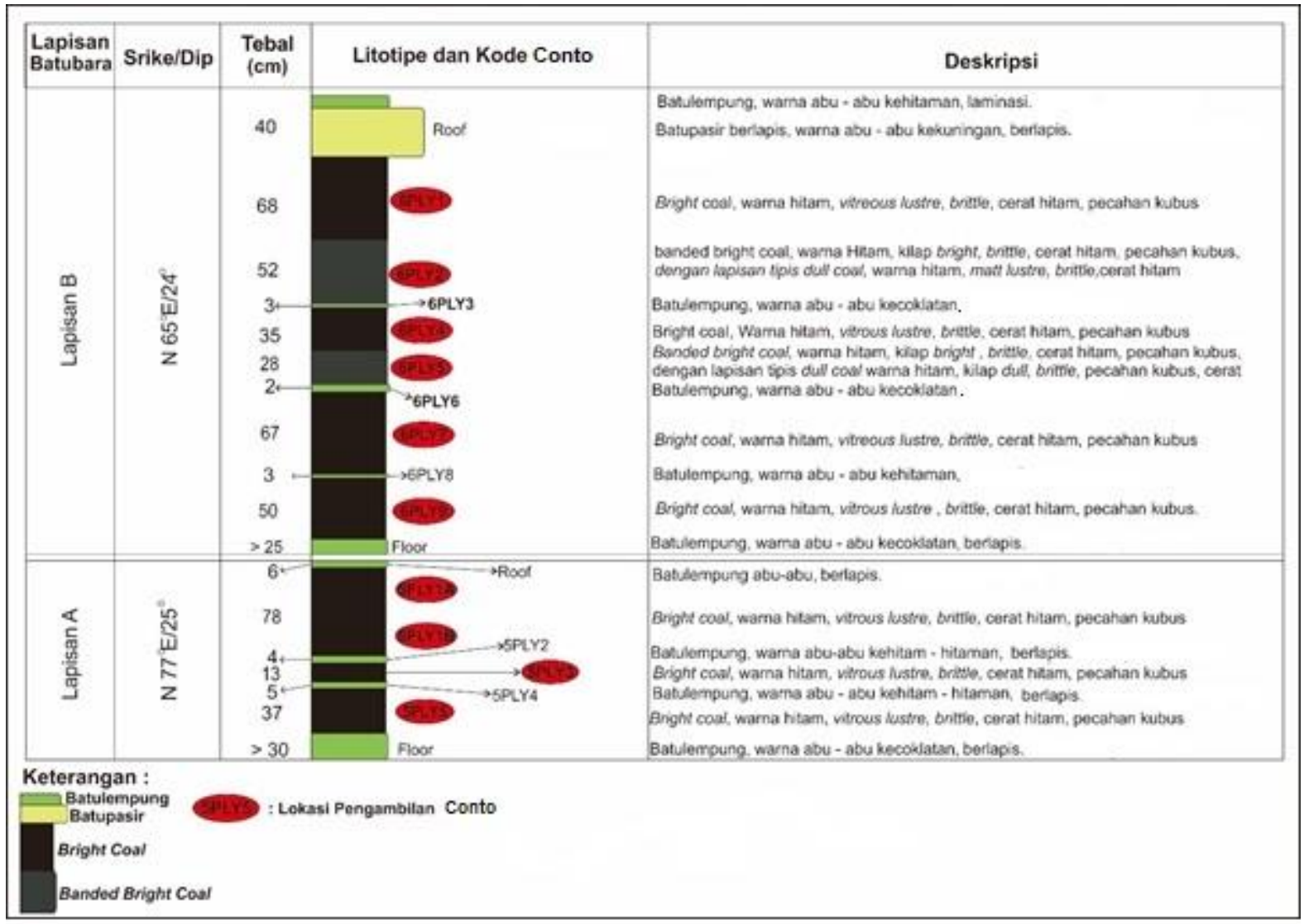

Gambar 4. Profil batubara lapisan A dan B Formasi Tanjung di daerah penelitian dan posisi pengambilan contonya

Tabel 1. Klasifikasi litotipe batubara subbituminus - bituminus

(modifikasi dari Diessel, 1965a dan Marchioni, 1980 dalam Lamberson et al., 1991)

\section{Nomenclature}

Bright coal

\section{Description}

Subvitrous to vitrous lustre, concoidal fracture, less than $10 \%$ dull laminae

Banded bright coal Predominantely bright coal, with $10-40 \%$ dull laminae

Banded coal Interbedded dull and bright coal in approximately equal proportion

Banded dull coal Predominantely dull coal with 10 - 40\% bright laminae

\begin{tabular}{ll}
\hline Dull coal & Matt lustre, uneven fracture, less than $10 \%$ bright coal laminae, hard \\
\hline Fibrous coal & Satin lustre, very friable, sooty to touch \\
\hline Sheared coal & $\begin{array}{l}\text { Variable lustre, disturbed bedding, numerous slip/slickemside surface } \\
\text { very brittle }\end{array}$ \\
\hline
\end{tabular}

\section{HASIL DAN PEMBAHASAN}

\section{HASIL}

Analisis makroskopis yang dilakukan terhadap batubara lapisan A yang memiliki ketebalan lebih kurang 1,5 meter (Gambar 4) menunjukkan bahwa batubara pada lapisan tersebut tersusun dominan oleh litotipe batubara mengilap (bright coal, yaitu 5PLY1A, 5PLY1B, 5PLY3 dan 5PLY5) dan terdapat 2 lapisan batulempung sebagai inorganic parting yaitu pada conto 5PLY2 dan 5PLY4 (Gambar 4). Batubara lapisan B memiliki ketebalan lebih kurang 3 meter (Gambar 4) tersusun dominan oleh litotipe batubara mengilap (bright coal, yaitu 6PLY1, 
6PLY4, 6PLY7, 6PLY9) dan litotipe batubara mengilap berlapis (banded bright coal, yaitu 6PLY2 dan 6PLY5) serta terdapat 3 lapisan batulempung sebagai inorganic parting yaitu pada conto 6PLY3, 6PLY6 dan 6PLY8. Batubara lapisan A memiliki kandungan abu 3,34 s.d. 9,05 ( $w t \%, a d b$ ), zat terbang 35,14 s.d. 36,60 ( $w t \%, a d b)$, dan maksimum fluiditas 22.710 s.d. 38.214 dial division per minute (ddpm). Sementara itu, batubara lapisan B memiliki kandungan abu 2,79 s.d. 5,78 (wt\%, adb), kandungan zat terbang 36,58 s.d. 39,50 (wt\%, adb) dan maksimum fluiditas 22.263 s.d. 49.029 ddpm (Tabel 2). Berdasarkan rentang nilai kandungan zat terbang berbagai peringkat batubara (Speight, 2005), batubara lapisan A dan B tersebut termasuk ke dalam batubara bituminus.

\section{PEMBAHASAN}

Kandungan zat terbang merupakan salah satu parameter yang berfungsi sebagai indikator peringkat batubara (Taylor et al. 1998; Diaz-Faes et al. 2007). Zat terbang secara komposisi kimia dominan tersusun atas fraksi non aromatik di dalam batubara (Taylor et al. 1998). Seiring dengan meningkatnya peringkat batubara dimana terjadi peningkatan derajat aromatisasi, maka kandungan zat terbang dan hidrogen di dalam batubara akan semakin menurun dan sebaliknya kandungan karbon dan karbon tertambat semakin meningkat (Diessel, 1992; Taylor et al. 1998; Smith dan Smith, 2007).

Hasil evaluasi menunjukkan bahwa trend dan korelasi antara kandungan abu, kandungan zat terbang dan maksimum fluiditas tidak terlihat jika analisis dilakukan per lapisan. Hal ini kemungkinan disebabkan karena conto batubara yang digunakan jumlahnya hanya sedikit (4 untuk lapisan A dan 6 untuk lapisan B). Untuk melihat kemungkinan adanya trend hubungan antara kadar abu, zat terbang dan maksimum fluditas yang berlaku umum analisis statistik dilakukan pada seluruh conto batubara di daerah penelitian tanpa membedakan lapisan (Gambar 5). Hasil analisis statistik uji regresi linear sederhana antara variabel independent $(x)$ zat terbang terhadap variabel dependent (y) maksimum fluiditas, menunjukkan angka koefisien regresi $(r)=0,794$, nilai signifikan $(\mathrm{sig})=$ 0,003 dan nilai koefisien determinasi $\left(R^{2}\right)$ $=0,6301$ (Gambar 5 dan Tabel 3). Hubungan antara kedua variabel ditunjukkan dengan persamaan $\mathrm{y}=$ $6327,9 x$ - 200248. Nilai $r$ mendekati 1 menunjukkan bahwa kedua variabel berkorelasi positif sementara nilai $r$ mendekat -1 menunjukkan bahwa kedua variabel yang diuji berkorelasi negatif, sementara nilai signifikansi $\leq 0,05$ menunjukkan bahwa variabel independent $(\mathrm{x})$ berpengaruh signifkan terhadap variabel dependent (y) (Sarwono, 2017). Berdasarkan data diatas, secara umum dapat disimpulkan bahwa kenaikan zat terbang berpengaruh signifikan terhadap kenaikan nilai maksimum fluditas. Sementara nilai koefisien determinasi $R^{2}=$ 0,6301 , menunjukkan bahwa pengaruh zat terbang terhadap maksimum fluiditas adalah sebesar $63,01 \%$ sementara pengaruh variabel bebas lainnya yang tidak diteliti adalah sebesar $36,9 \%$.

Tabel 2. Analisis Proksimat dan Gieseler Plastometer batubara lapisan A dan B Formasi Tanjung di Sekako, Provinsi Kalimantan Tengah

\begin{tabular}{lcccccccccc}
\hline \multirow{1}{*}{ Analisis } & \multicolumn{1}{c}{ Lapisan A } & \multicolumn{1}{c}{ Batubara } \\
\cline { 2 - 11 } & 5PLY1A & 5PLY1B & 5PLY3 & 5PLY5 & 6PLY1 & 6PLY2 & 6PLY4 6PLY5 & 6PLY7 & 6PLY9 \\
\hline $\begin{array}{l}\text { Kandungan abu } \\
\text { (wt\%, adb) }\end{array}$ & 3,95 & 3,34 & 8,81 & 9,05 & 5,78 & 2,79 & 3,39 & 4,71 & 4,29 & 4,01 \\
\hline $\begin{array}{l}\text { Kandungan zat } \\
\text { terbang (wt\%, adb) }\end{array}$ & 36,60 & 35,68 & 35,14 & 35,76 & 39,50 & 37,95 & 37,72 & 37,29 & 37,06 & 36,58 \\
\hline $\begin{array}{l}\text { Maksimum } \\
\text { Fluiditas (ddpm) }\end{array}$ & 38214 & 22710 & 22860 & 29268 & 49029 & 46833 & 43341 & 22263 & 29052 & 30702 \\
\hline
\end{tabular}

Keterangan: persen berat (wt\%), air dried basis (adb), dial division per minute (ddpm) 
Secara umum semakin tinggi kandungan zat terbang maka maksimum fluiditas batubara semakin tinggi. Hal tersebut terjadi karena zat terbang pada umumnya tersusun atas senyawa gas yang bersifat mudah terbakar (flammable/combustible) yang meliputi hydrogen $(\mathrm{H})$, karbon monoksida (CO), metana $\left(\mathrm{CH}_{4}\right)$ dan ditambah dengan senyawa hidrokarbon lainnya serta tar (Speight, 2013; Thomas, 2013). Semakin banyak kandungan zat terbang maka rasio $\mathrm{H} / \mathrm{C}$ akan semakin tinggi (Shui et al. 2011). Selama proses karbonisasi, zat terbang membentuk tar dan gas (Miller, 2005; Ryemshak dan Jauro, 2016). Hal tersebut juga menunjukkan bahwa semakin rendah peringkat batubara dimana zat terbangnya semakin tinggi, maka nilai maksimum fluiditas akan semakin tinggi (Diaz-Faes et al. 2007; Vega et al. 2017).

Di dalam proses analisis korelasi antara variabel kandungan abu dan maksimum fluiditas terdapat tiga data outlier yaitu conto 5PLY3, 5PLY5 dan 6PLY1 (Gambar $5 B)$. Dibandingkan dengan conto lain, kandungan abu conto 5PLY3 dan 5PLY5 relatif lebih tinggi sehingga dalam penelitian ini kedua conto berada dalam zona outlier. Sementara itu conto 6PLY1 memiliki kandungan zat terbang yang relatif lebih tinggi dibandingkan dengan conto lain, sehingga juga berada dalam zona outlier. Analisis regresi linier sederhana menunjukkan bahwa variabel kandungan abu memiliki korelasi negatif terhadap maksimum fluiditas batubara yang dapat ditunjukkan dengan persamaan regresi $y=-9838,9 x+70522$ dengan $r=-0,656$. Kandungan abu tidak berpengaruh signifikan terhadap maksimum fluiditas (sig. 0,055 > 0,05) serta memiliki nilai koefisien determinasi atau $R^{2}=0,4315$ (Gambar 5B dan Tabel 3).

Secara umum, dalam penelitian ini terlihat bahwa semakin tinggi kandungan abu maka semakin rendah nilai dari maksimum fluiditas batubara (Gambar 5B). Hal yang sama juga dinyatakan oleh Arslan dan Kemal (2006) bahwa semakin tinggi kandungan abu batubara maka maksimum fluiditas semakin rendah. Kandungan abu berpengaruh terhadap nilai maksimum fluiditas batubara sebesar 43,15\% sementara faktor lain berpengaruh sebanyak $56,85 \%$. Kandungan mineral yang terdapat di dalam abu batubara umumnya bertindak sebagai inert material (Ryan et al. 1998) dan abu berasal dari komponen yang tidak terbakar di dalam batubara (Sukandarrumidi, 2009). Kandungan abu yang tinggi akan berdampak negatif terhadap kekuatan dan kemampuan kokas di dalam blast furnace (Ryemshak dan Jauro, 2013; Riddell and Han, 2017). Kandungan abu yang tinggi dalam batubara akan menurunkan tingkat efisiensi gas yang dihasilkan, yang disebabkan oleh terjadinya peningkatan komposisi oksigen. Peningkatan komposisi oksigen di dalam batubara akan menurunkan suhu pemanasan atau pembakaran (Suarez-Ruiz dan Crelling, 2008). Gugus fungsional oksigen pada saat proses pirolisis atau karbonisasi berlangsung akan menghabiskan elemen hidrogen aktif dalam jumlah yang banyak (Shui et al. 2011). 


\section{MAKALAH ILMIAH}

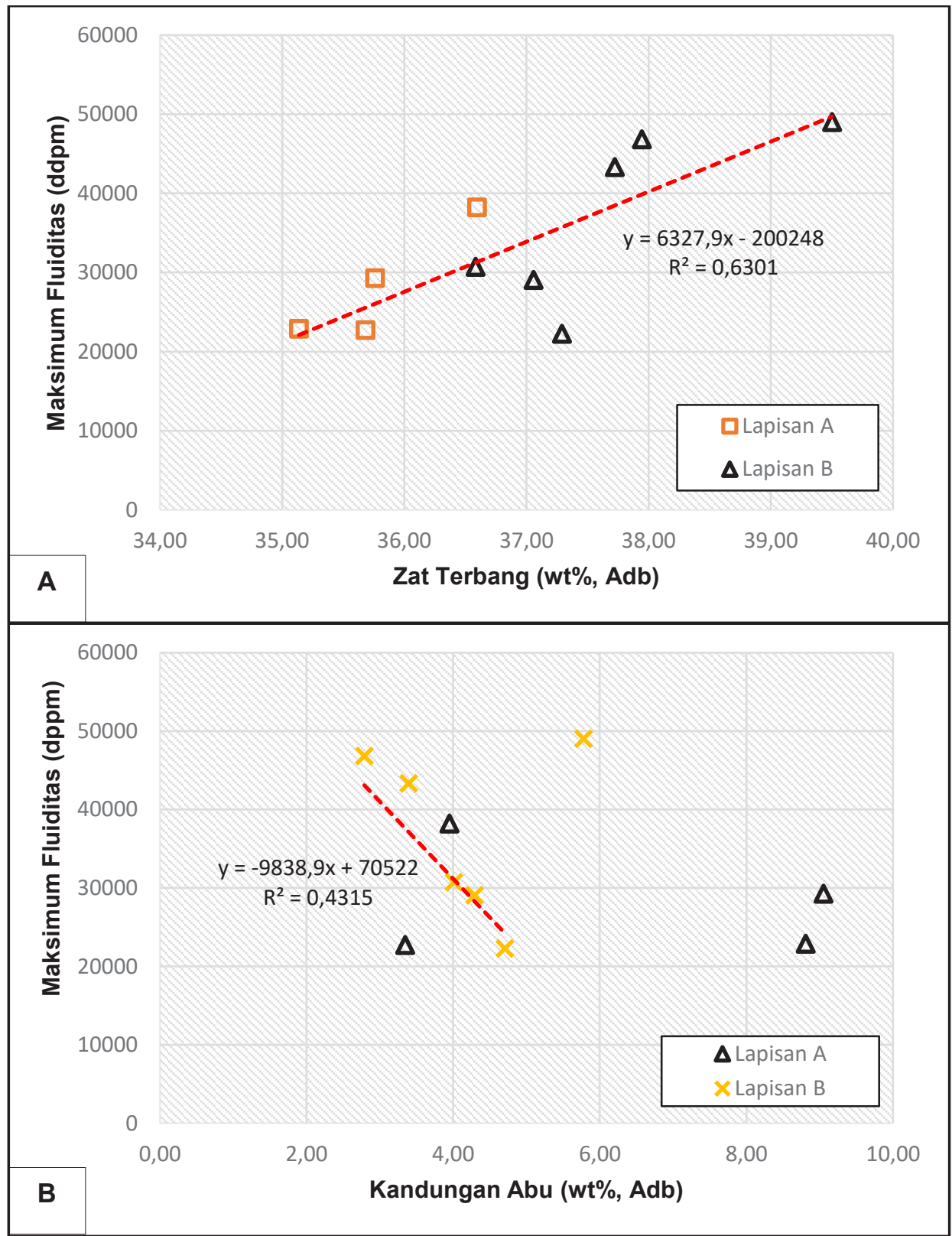

Gambar 5. (A) Diagram pencar hubungan antara kandungan zat terbang dengan maksimum fluiditas batubara dan (B) kandungan abu dengan maksimum fluiditas batubara beserta rumus korelasinya

Tabel 3. Analisis regresi linier sederhana variabel bebas zat terbang dan kandungan abu terhadap maksimum fluiditas batubara

\begin{tabular}{|c|c|c|c|c|c|c|}
\hline \multirow[b]{2}{*}{ No } & \multirow[b]{2}{*}{ Data Variabel } & \multicolumn{3}{|c|}{ Analisis Data } & \multicolumn{2}{|c|}{$\mathbf{N}$} \\
\hline & & $\mathbf{r}$ & $\mathbf{R}^{2}$ & Sig & Outlier & $\begin{array}{c}\text { Data } \\
\text { Analisis }\end{array}$ \\
\hline 1 & $\begin{array}{l}\text { Hubungan kandungan abu (adb) } \\
\text { terhadap maksimum fluiditas (ddpm) }\end{array}$ & $-0,656$ & 0,4315 & 0,055 & 3 & 7 \\
\hline 2 & $\begin{array}{l}\text { Hubungan kandungan zat terbang } \\
(\mathrm{adb}) \text { terhadap maksimum fluiditas } \\
(\mathrm{ddpm})\end{array}$ & 0,794 & 0,6301 & 0,003 & 0 & 10 \\
\hline
\end{tabular}

Keterangan: Koefisien korelasi (r), Koefisien determinasi $\left(R^{2}\right)$, Signifikansi (Sig), Jumlah data (N), air dried basis (adb), dial division per minute (ddpm). 


\section{KESIMPULAN DAN SARAN}

Batubara Formasi Tanjung di Daerah Sekako, Kalimantan Tengah didominasi oleh litotipe batubara mengilap dan batubara mengilap berlapis yang memiliki kandungan abu 2,79 s.d. 9,05 (wt\%, adb), zat terbang 35,14 s.d. 39,50 (wt\%, adb) dan maksimum fluiditas 22.263 s.d. 49.090 (ddpm).

Kandungan abu berkorelasi negatif kuat $\left(r=-0,656 ; R^{2}=0,431\right)$ dan tidak berpengaruh signifikan (sig. 0,055 >0,05) terhadap maksimum fluiditas batubara. Sementara itu, kandungan zat terbang berkorelasi positif kuat $\left(r=0,794 ; R^{2}=\right.$ 0,630 ) dan berpengaruh signifikan (sig. $0,003<0,05)$ terhadap maksimum fluiditas batubara. Secara umum data menunjukkan bahwa semakin tinggi kandungan abu maka maksimum fluiditas batubara semakin rendah, dan sebaliknya semakin tinggi zat terbang maka semakin tinggi juga nilai maksimum fluiditas.

Nilai maksimum fluiditas batubara dapat diperkirakan berdasarkan kandungan zat terbang-nya. Hubungan kandungan zat terbang dengan maksimum fluiditas batubara dapat dinyatakan dengan persamaan $y=6327,9 x-200248$.

Untuk memahami karakteristik metalurgi batubara Indonesia, pemahaman secara menyeluruh terkait pengaruh dan hubungan karakteristik batubara dengan maksimum fluiditas sangat diperlukan. Untuk meningkatkan pemahaman terhadap pengaruh dan hubungan antara karakteristik batubara lainnya terhadap maksimum fluiditas batubara, diperlukan jumlah conto yang lebih banyak disamping analisis lebih lanjut terkait petrografi batubara, analisis kimia batubara (FTIR, $\mathrm{XRD}$, ash fusion) dan juga analisis kandungan mineral dalam batubara.

\section{UCAPAN TERIMA KASIH}

Penulis mengucapkan terima kasih kepada PT Suprabari Mapanindo Mineral (PT SMM) atas ijin untuk pengambilan conto batubara. Studi ini dilakukan dengan dukungan dana penelitian dari Departemen Teknik Geologi, Universitas Gadjah Mada.

\section{DAFTAR PUSTAKA}

Amarullah, D., 2009. Suatu Pemikiran Untuk Memanfaatkan Potensi Batubara Formasi Tanjung di Daerah Lemo Kalimantan Tengah Sebagai Kokas. Kelompok Program Penelitian Energi Fosil, Pusat Sumber Daya Geologi, Bandun. v. 4, p. 1-11.

Arslan, V., dan Kemal., M., (2006): The Effect of Inert Matters and Low Volatile Coal Addition on The Plasticity of High Volatile Zonguldak Coals. The Journal of The South African Institute of Mining and Metallurgy. v. 106, p. 199-204.

Badan Nasional Penanggulangan Bencana, 2009. Peta Pulau Kalimantan: geospasial.bnpb.go.id (diakses pada Mei 2018).

Darman, H., and Sidi, F.H., 2000. An Outline of The Geology of Indonesia. Ikatan Ahli Geologi Indonesia, Jakarta. $254 \mathrm{p}$.

Daulay, B., Santoso, B., Ningrum, N.S., 2015. Evaluation of Selected High Rank Coal in Kutai Basin, East Kalimantan Relating to Its Coking Properties. Indonesian Mining Journal. v. 18, No. 1., p. 1-10.

Diessel, C.F.K., 1992. Coal-Bearing Depositional System. Thompson Press (India) Ltd., New Delhi. 679 p.

Diaz-Faes, E., Barriocanal, C., Diez, M.A., Alvarez, R., 2007. Characterization of Different Origin Coking Coals and Their Blends by Gieseler Plasticity and TGA. Journal of Analytical and Applied Pyrolisis. Elsevier. v. 80, p. 203-208.

Diez, M.A., Alvarez, R., Barriocanal, C., 2002. Coal for Metallurgical Coke Production: Prediction of Coke Quality and Future Requirements for Coke Making. International Journal of Coal Geology, Elsevier. v. 50, p. 389-412. 
Doust, H., and Sumner, H.S., 2007. Petroleum systems in rift basins - a collective approach in Southeast Asian basins. Petroleum Geoscience. v. 13, p. 127-144.

Friederich, M.C., Moore, T.M., Flores, R.M., 2016. A Regional Review and New Insights Into SE Asian Cenozoic Coal-Bearing Sediments: Why Does Indonesia Have Such Extensive Coal Deposits?. International Journal of Coal Geology, Elsevier. v. 166, p. 2-35.

Friederich, M.C., dan van Leeuwen, T., 2017. A Review of The History of Coal Exploration, Discovery and Production in Indonesia : The Interplay of Legal Framework, Coal Geology and Exploration Strategy. International Journal of Coal Geology, Elsevier. v. 178, p. 56-73.

Hall, R., and Morley, C.K., 2004. Sundaland Basins. In: Clift, P., Wang, P., Kuhnt, W., Hayes, D. E. (Eds.), Continent-Ocean Interactions within the East Asian Marginal Seas. AGU Geophysical Monograph, v. 149 , p. 55-85.

Hamilton, W., 1979. Tectonics of the Indonesian Region. U.S.G.S. Prof. Paper, 1078, $345 \mathrm{p}$.

Heryanto, R., 2010. Geologi Cekungan Barito. Badan Geologi, Kementerian Energi Dan Sumber Daya Mineral, Bandung. $139 \mathrm{p}$.

Huda, M., 2013. Potensi Coking Coal Indonesia Untuk Mendukung Industri Peningkatan Nilai Tambah (PNT) Mineral. M\&E. v. 11, No. 1, p. 44-53.

Hutchison, C.S., 1989. Geological evolution of South East Asia. Oxford Monograph on Geology and Geophysics. v. 13, 376 p. http://dx.doi.org/10.1016/j.palaeo.20 11.04.008.
Isnadiyati, O.F., Wiranata, B., Perdana, A.R., Tanggara, D.N.S.P., Amijaya, H., 2018. Interpretasi Stacked Mire Sequence Berdasarkan Litotipe Pada Batubara Coking Formasi Tanjung di Daerah Sekako, Kalimantan Tengah. Seminar Nasional Kebumian, Yogyakarta. v. 11. p. 31.

Lamberson, M.N., Bustin, R.M., Kalkreuth, W., 1991. Lithotype (maceral) Composition and Variation As Correlated With Paleo-Wetland Environments, Gates Formation, Northeastern British Columbia, Canada. International Journal of Coal Geology, Elsevier. v. 18, p. 87124.

Madiadipoera, T., and Trafimov, G., 1969. Report on Prospecting Reconnaissance Survey at Mamahak Besar and Sungai Kalian (Upper Course of Mahakam River Region), East Kalimantan, 19641965. Archives of the Centre for Geological Resources, Geological Agency, Bandung, Indonesia.

Miller, B.G., 2005. Coal Energy Systems. Elsevier Academic Press, USA. $526 \mathrm{p}$.

Mochizuki, Y., Naganuma R., Uoebo, K., Tsubouchi, N., 2017. Some Factors Influencing The Fluidity of Coal Blends : Particle Size, Blend Ratio and Inherent Oxygen Species. Fuel Processing Technology, Elsevier. v. 159 , p. 67-75.

Nas, C., dan Hindartan, 2010. The Quality of Central Kalimantan Coking Coals. Kalimantan Coal and Mineral Resources. Proceeding MGEI-IAGI, Balikpapan, p. 1-11.

Riddell, J., dan Han, T., 2017. Ash Chemistry Database for British Columbia Rocky Mountain Bituminous Coals. British Columbia Geological Survey. v. 10, 15 p. 
Ryan, B., Gransden J., dan Price, J., 1998. Fludity of Western Canadian and Its Relationship to Other Coal and Coke Properties. British Columbia Geological Survey, 17 p.

Ryemshak, S.A., dan Jauro, A., 2016. Proximate analysis, Rheological Properties and Technological Application of Some Nigerian Coals. International Journal of Industrial Chemistry (IJIC). v. 4, p. 1-7.

Sarwono, J., 2017. Mengenal Prosedur Prosedur Popula Dalam SPSS 23. PT. Gramedia, Jakarta. 272 p.

Satyana, A.H., and Silitonga, P.D., 1994. Tectonic Reversal in East Barito Basin, South Kalimantan: consideration of the types of inversion structures and petroleum system significance. Proceedings of the IPA $23^{\text {rd }}$ Annual Convention. p. 57-74.

Shui, H., Li, H., Chang, H., Wang, Z., Gao, Z., Lei, Z., Ren, S., 2011. Modification of Sub-Bituminous Coal by Steam Treatment: Caking and Coking Properties. Fuel Processing technology, Elsevier. v. 92, p. 22992304.

Smedowski, L., and Piechaczek, M., 2016. Impact Of Weathering on Coal Properties And Evolution of Coke Quality Described By Optical and Mechanical Parameters. International Journal Of Coal Geology, Elsevier. v. 168, p. 119130.

Smith J.R., dan Smith, J.W., 2007. A Relationship Between the Carbon and Hydrogen Content of Coals and Their Vitrinite Reflectance. International Journal of Coal Geology, Elsevier. v. 70, p. 79-86.

Soetrisno, Supriatna, S., Rustandi, E., Sanyoto, P., and Hasan, K., 1994. Geological Map of The Buntok Quadrangle, Kalimantan. Geological Research and Development Centre, Bandung. $1 \mathrm{p}$.
Speight, J.G., 2005. Handbook of Coal Analysis, John Wiley and Sons, Inc., Hoboken, New Jersey. 222 p.

Speight, J.G., 2013. The Chemistry and Technology of Coal, $3^{\text {rd }}$ Edition. CRC Press. Taylor \& Francis Group, London. $779 \mathrm{p}$.

Suarez Ruiz, I., and Crelling, C.J., 2008. Applied Coal Petrology. Elsevier. $388 \mathrm{p}$.

Sukandarrumidi, 2009. Batubara dan Pemanfaatannya. Gadjah Mada University Press, Yogyakarta. 247 p.

Supriatna, S., Sudrajat, A., and Abidin H.Z., 1995. Geological Map of The Muara Teweh Quadrangle Kalimantan. Geological Research and Development Centre, Bandung. $1 \mathrm{p}$.

Taylor, G.H., Teichmuller, M., Davis, A., Diessel, C.F.K., Littke, R., Robert, P., 1998. Organic Petrology. Gebrueder Borntraeger, Stuttgart. $704 \mathrm{p}$.

Thomas, L., 2013. Coal Geology, $2^{\text {nd }}$ Edition. Willey-Blackwell, John Willey \& Son Ltd., 431 p.

Tsubouchi, N., Mochizuki, Y., Ono, Y., Eebo, K., Takanohashi, T., Sakimoto, N., 2014. Sulfur and Nitrogen Distribution During Coal Carbonzation and The Influence of These Elements on Coal Fluidity and Coke Strength. ISIJ International. v. 54, p. 2439-2445.

Vega, M.F., Fernandez, A.M., Diaz-Faes, E., Barriocanal, C., 2017. Improving The Properties of High Volatile Coking Coals by Controlled Mild Oxidation. Fuel, Elsevier. v. 191, p. 574-582.

Witts, D., Hall, R., Nichols, G., dan Morley, R., 2012. A New Depositional and Provenance Model for The Tanjung Formation, Barito Basin, SE Kalimantan, Indonesia. Journal of Asia Earth Science, Elsevier. v. 56, p. $77-104$.

\begin{tabular}{|ll|}
\hline Diterima & $:$ 30 Januari 2019 \\
Direvisi & $:$ 20 November 2019 \\
Disetujui & $:$ 31 Agustus 2020 \\
\hline
\end{tabular}

